\title{
UNIVERSITY OF LEEDS
}

This is a repository copy of Privileges and penalties in the legal profession: an intersectional analysis of career progression.

White Rose Research Online URL for this paper:

http://eprints.whiterose.ac.uk/128629/

\section{Version: Accepted Version}

\section{Article:}

Tomlinson, J orcid.org/0000-0002-1863-885X, Valizade, D orcid.org/0000-0003-3005-2277, Muzio, D et al. (2 more authors) (2019) Privileges and penalties in the legal profession: an intersectional analysis of career progression. British Journal of Sociology, 70 (3). pp. 1043-1066. ISSN 0007-1315

https://doi.org/10.1111/1468-4446.12375

(C) 2018, London School of Economics and Political Science. This is the peer reviewed version of the following article: Tomlinson, J. , Valizade, D. , Muzio, D. , Charlwood, A. and Aulakh, S. (2018), Privileges and penalties in the legal profession: an intersectional analysis of career progression. The British Journal of Sociology., which has been published in final form at https://doi.org/10.1111/1468-4446.12375. This article may be used for non-commercial purposes in accordance with Wiley Terms and Conditions for Self-Archiving. Uploaded in accordance with the publisher's self-archiving policy.

\section{Reuse}

Items deposited in White Rose Research Online are protected by copyright, with all rights reserved unless indicated otherwise. They may be downloaded and/or printed for private study, or other acts as permitted by national copyright laws. The publisher or other rights holders may allow further reproduction and re-use of the full text version. This is indicated by the licence information on the White Rose Research Online record for the item.

\section{Takedown}

If you consider content in White Rose Research Online to be in breach of UK law, please notify us by emailing eprints@whiterose.ac.uk including the URL of the record and the reason for the withdrawal request. 


\title{
Privileges and Penalties in the Legal Profession: An intersectional
}

\author{
analysis of career progression
}

\author{
Jennifer Tomlinson, University of Leeds, U.K. \\ Danat Valizade, University of Leeds, U.K. \\ Daniel Muzio, Newcastle University, U.K. \\ Andy Charlwood, University of Leeds, U.K. \\ Sundeep Aulakh, University of Leeds, U.K.
}

\begin{abstract}
Intersectionality theory is concerned with integrating social characteristics to better understanding complex human relations and inequalities in organizations and societies (McCall 2005). Recently, intersectionality research has taken a categorical and quantitative turn as scholars critically adopt but retain existing social categories to explain differences in labour market outcomes. A key contention is that social categories carry penalties or privileges and their intersection promotes or hinders the life chances of particular groups and individuals. An emergent debate is whether the intersection of disadvantaged characteristics (such as female gender or minority ethnic status) produce penalties that are additive, multiplicative or ameliorative. Research is inconclusive and as yet pays little attention to moderating factors such as employer type, size, geographic location or work profile. Drawing on administrative records for individuals qualified as solicitors in England and Wales, collected by the Solicitors Regulation Authority (SRA), combined with aggregated workforce data and firm characteristics of their law firms, we undertake a statistical analysis of the intersection of gender and ethnicity in the profession with a degree of precision and nuance not previously possible. In response to calls to broaden studies of inequalities and intersectionality beyond their effect on pay or income (Castilla, 2008) we focus on career progression to partnership as our key measure of success. The original contribution of our study is twofold. First, we establish statistically different profiles of law firms, showing how the solicitors' profession is stratified by gender, ethnicity and socioeconomic background, as well as the type of legal work undertaken by developing a model of socio-economic stratification in the profession. Second, we demonstrate that while penalties tend to be additive (i.e. the sum of the individual ethnic and gender penalties) this varies significantly by law firm profile and in some situations the effect is ameliorative.
\end{abstract}

Keywords: intersectionality, gender, ethnicity, solicitors' profession, career progression 


\section{Introduction}

Intersectionality theory is a major contribution of feminist scholarship to sociology (Browne and Misra 2003; McCall 2005). It is concerned with integrating social characteristics to better understanding complex human relations and inequalities in organizations and societies (Acker 2006; Walby 2012). Early work took an anti-categorical position (McCall 2003) rejecting or problematizing fixed social categories such as gender, class or ethnicity focusing instead on the multi-layered experiences of individuals or communities (Yuval-Davis 2007), often through in depth qualitative studies (McCall 2005). Recently, intersectional research has taken a categorical and quantitative turn as scholars critically adopt but retain existing social categories to explain differences in labour market outcomes, notably inequalities in pay (Greenman and Xie 2008; Mandel and Semyonov 2016; Woodhams et al. 2015). A key contention is that social categories carry privileges or penalties and their intersection promotes or hinders the life chances of particular groups or individuals.

Within this context, an emergent debate is whether the intersection of characteristics associated with labour market penalties (such as female gender or minority ethnic status) is additive (Brown and Misra 2003), multiplicative (Woodhams et al. 2015) or ameliorative (Mandel and Semyonov 2016). Research is inconclusive and as yet pays little attention to factors that moderate combinations of privileges and penalties such as employer type, size, geographic location or work profile. This is surprising given research demonstrates these factors structure opportunities and rewards (Wilkins and Gulati 1996; Gorman 2005; Gorman and Kmec 2009; Briscoe and Kellogg 2011; Bidwell et al. 2013).

Drawing on administrative records for individuals qualified as solicitors in England and Wales, routinely collected by the Solicitors Regulation Authority (SRA), combined with aggregated workforce data and law firm characteristics, we have undertaken a statistical 
analysis of the intersection of gender and ethnic privileges and penalties in the profession with a degree of precision and nuance not previously possible. In response to calls to broaden studies of inequalities and intersectionality beyond effects on pay or income (Castilla, 2008) or entry to professions (Friedman and Laurison 2017), we focus on career progression to partnership as our key measure of success.

The original contribution of our study is twofold. First, we establish five statistically different law firm profiles, showing how the solicitors' profession is stratified by gender, ethnicity and socio-economic background, as well as the type of legal work undertaken. Second, we demonstrate that while penalties tend to be additive (the sum of the individual ethnicity and gender penalties) this varies significantly by law firm profile and in some situations the effect is ameliorative.

The paper begins by reviewing intersectionality theory and labour market inequalities, making a case for why this issue is worthy of attention. It then details the context of the solicitors' profession in England and Wales, before presenting data, methods and results relating to the two areas of contribution outlined above.

\section{Intersectionality theory and intersecting penalties}

Intersectionality scholars argue that lived experiences of individuals and communities cannot be adequately captured by analysis of one social characteristic, an approach termed 'single axis' analysis (Hill Collins 1993). Instead, they seek to understand 'the complexity that arises when the subject of analysis expands to include multiple dimensions of social life' (McCall 2005: 1772). Within intersectionality research a central concern is for analysis of both inter and intra group differences, recognizing that the interpenetration of complex 
inequalities can be reinforcing or contradictory (Acker 2006), or parallel and interlocking, at times but not always, oppositional (Hill Collins 1993).

While feminists have been working with the principle of intersectionality, notably gender and ethnicity, since the 1970s and 1980 (hooks 1984; Anthias and Yuval Davis 1993), the term is most frequently attributed to Kimberley Crenshaw. Her starting point is that when feminist analyses focus on white middle class women's issues or 'on the most privileged group members [this] marginalizes those who are multiply-burdened and obscures justice claims that cannot be understood as resulting from discrete sources of discrimination' (Crenshaw 1989: 140).

Crenshaw's critique is central to debates on how to operationalise intersectional research in the social sciences (1993). One major challenge for researchers is how to do justice to both inter and intra group differences and the utility of existing social categories such as 'gender', 'race' or 'class' (Walby et al. 2012). In response to this dilemma McCall (2005) outlines three approaches to intersectionality research, each attempting to 'satisfy demands for complexity'. These are anti-categorical, intra-categorical and inter-categorical. Anticategorical approaches reject the use of socially constructed categories, arguing human relations are too complex to be adequately analysed using fixed categories or units of analysis. Scholars adopting an anti-categorical approach deconstruct fixed social categories, problematising their social construction (McCall 2005). Such accounts emphasize that identity politics are multi-layered - individuals belong simultaneously to multiple political communities (Yuval Davis 2007). Intersectionality should, therefore, emphasise fluidity, connections and parallels between the identity claims and politics (Hill Collins 1993). Such analyses are typically approached using qualitative methodologies.

In contrast, intra-categorical research makes use of existing social categories, treating them critically, and in doing so focuses on neglected, or new, points of intersection - people whose 
identities cross over the boundaries of traditionally constructed groups (McCall 2003). Such an approach is informed by Crenshaw $(1989 ; 1993)$ who urges scholars to focus on intersections to illuminate the experiences of those at the margins of social categories due to multiple or competing axes of disadvantage.

According to McCall (2005) a third way of studying intersectionality, currently under-utilised, is 'inter-categorical complexity'. Rather than rejecting existing social categories, this approach uses them strategically to document relationships of inequality among and between groups. Categories, though imperfect and prone to change, are used as anchor points. McCall (2005) shows how the application of a systematic multi-group comparative analysis incorporating gender, class and ethnicity can lead to rich analyses of labour market outcomes. Various recent studies have adopted a similar approach with illuminating results (Greenman and Xie 2008; Woodhams et al. 2015; Mandel and Semyonov 2016) showing how an inter-categorical approach can systematically analyse the intersection of multiple axes of discrimination, and measure social characteristics associated with labour market privilege and penalties.

\section{Mapping intersections of privilege and penalty: additive assumptions and alternatives}

Debates on how penalties manifest are ongoing and inconclusive - research reveals different tendencies. The most common way of articulating intersecting penalties is to say they are additive or that those with two disadvantaged characteristics face a 'double jeopardy' (Browne and Misra 2003). The additive assumption is, Greenman and Xie (2008) argue, precisely that: rarely tested or found to be empirically correct. They claim most researchers invoke it 'implicitly, when [they] draw references about a race gap and a gender gap' (2008:1218). They show that when single axis analyses are performed, the ability to 
test the additive assumption is lost. A second hypothesis is that intersectional penalties are multiplicative - greater than the sum or addition of two or more intersecting disadvantaged characteristics (Woodhams et al 2015). Alternatively, intersectional characteristics can be ameliorative - characteristics associated with disadvantage might off-set each other resulting in a penalty less than the sum of each. What does the evidence suggest about these debates?

Crenshaw, approaching the challenge of intersectionality through the lens of how courts frame and interpret the stories of Black women plaintiffs, argues that 'the intersectional experience is greater than the sum of racism and sexism' (1989: 140). Put another way, it is beyond additive, and to make an 'additive assumption' does not do justice to the complex way identity characteristics associated with disadvantage interact, with the potential to exacerbate or magnify experiences of marginalisation. Studies that have taken an anticategorical approach have in the past supported such a contention and, until recently, quantitative research was lacking.

Woodhams' et al (2015) study of pay penalties in a large UK based organisation is instructive in this respect. They focus on pay gaps and multiple (cumulative) disadvantage concerning gender, ethnicity, age and disability. The analysis is based on multiple years of pay data and shows that individuals with more than one disadvantaged identity characteristic suffer a significantly greater pay penalty than those with a single disadvantaged characteristic. The data also provides evidence that penalties associated with multiple disadvantages exponentially increase, or put another way, exhibit a 'snowballing effect' - pay gaps are far greater than would arise from simply adding together the pay penalties from single characteristics.

In contrast, Greenman and Xie (2008) problematize the additive assumption by showing how gender pay gaps vary across different ethnic groups. They find that white women 
experience a larger gender pay penalty than women of any minority ethnic group. Furthermore, in a detailed analysis income in the USA between 1970 and 2010, Mandel and Semyonov (2016) find that contrary to the double jeopardy hypothesis black men experience a larger ethnic pay penalty than black women do (Mandel and Semyonov 2016: 1058). This supports Greenman and Xie's claim that minority ethnic women do not always experience the 'full disadvantage of each status' (2008: 1217).

Within the existing literature there is a lack of attention to the role of organizational characteristics in moderating the distribution of opportunities and rewards to different groups (Bidwell et al 2013; Briscoe and Kellogg 2011; Friedman and Laurison 2017; Gorman and Kmec 2009; Wilkins and Gulati 1996). We think this omission is important and we address this by looking at how intersecting labour market penalties and privileges vary by different firm characteristics and workforce composition in the legal profession.

\section{The social structure of the legal profession and inequality}

The solicitors' profession in England and Wales is bifurcated between large legal practices servicing national and multi-national corporate clients, and regional and local firms mainly advising the private client market (Law Society 2012). Within this broad structure the profession is characterized by horizontal segmentation and vertical stratification. That is, minorities tend to cluster in the least lucrative segments of the market, often working in small firms and advising on the everyday civil, family and administrative justice problems as opposed to, for example, overseeing multibillion-pound transactions in elite law firms (Dixon and Seron 1995; Sommerlad and Sanderson 1998; Bolton and Muzio 2007). Vertical stratification within firms results in fewer opportunities for women and minorities to make partnership compared with their white male counterparts (Kay and Hagan 1998; Gorman 2006; Gorman and Kmec 2009). This is attributed to a series of occupational and 
organizational structures and cultural practices which advantage white middle and upperclass men and marginalize women and minority ethnic groups (Wilkins and Gulati 1996; Tomlinson et al. 2013; Kay and Gorman 2008).

An insightful illustration of this is the tournament promotion system (Galanter and Palay 1991) which are highly institutionalized within large commercially focused law firms (Malhotra et al. 2010). These rely on taking on a higher number of recruits than are required by the firm's partner succession planning, resulting in fierce competition between recruits as they battle for a limited number of promotions. The losers in this tournament will quit, relocating to a different and likely less prestigious firm, or move to work as solicitors within non-legal organisations (working 'in house'). As such these are known as up-or-out promotion systems.

Tournaments do not take place on a level playing field - they privilege, often latently, white middle and upper-class males. All other things being equal, performance in the tournament depend on mentoring and coaching opportunities as well as on access and exposure to the right types of projects and clients to facilitate rainmaking (Sommerlad et al 2013). Research shows that minority groups are less likely to receive 'interesting work, meaningful training, supervision and supportive mentors' (Wilkins and Gulati 1996: 656). The division of domestic and parental responsibilities means that in many situations women are less likely to be able to commit to the significant investments in resources required for success in the tournament (Kay and Hagan 1995; Tomlinson et al. 2013).

Furthermore, crucial evaluations are typically made by existing middle class white male partners who tend to favour those similar to them (Gorman and Kmec 2009). As such, promotion judgments are based on certain symbols which act as proxies for quality, performance and reputation (Hanlon 2004; Ashley and Empson 2013). These symbols include forms of social and cultural capital such as accents, self-presentation, taste, interests 
and mutual connections; all things which have clear gender, ethnic and class dimensions (Webley et al 2016). Firms tend to recruit and promote people who display the right signifiers as these are viewed as less risky options. Recruiting certain types of candidates (white men from advantaged backgrounds) makes commercial sense and explains why inequality is reproduced in elite firms despite their public commitment to diversity management discourses and practices (Ashley and Empson 2013, 2017).

Responses to closure processes (Parkin 1979; Witz 1990) can take various forms. Female lawyers may shift towards in house roles or non-partnership tracks where these exists (Malhotra et al. 2010) whilst minority ethnic solicitors may cluster in 'ethnic' firms or chambers (Ladinsky 1963; Heinz et al. 2005), as historically demonstrated by the development of Jewish law firms in response to overt discrimination within Wall street firms (Wald, 2008). They may specialize in areas of law which offer fewer barriers to entry or are more conducive to their work-lifestyle preferences (Bolton and Muzio 2007 Sommerlad and Sanderson 1998; Sommerlad et al 2013). These areas are usually identified with the personal hemisphere of law (Heinz and Lauman 1982) insofar they are focused on the solution of the everyday problems experienced by individuals and communities. Indeed many solicitors may find greater intrinsic value in these forms of legal work, which include family, immigration, criminal, probate and housing law and contrast with the corporate law which focuses on the problems of the large organizations. The net result of these tendencies is a process of horizontal segmentation whereby the profession is divided in a number of segments with different rewards, career opportunities and working conditions, with women and minority professionals less likely to progress within the most lucrative segments.

Existing research on equality and diversity in the legal profession has mainly focused on the corporate sector. Little is known about the career outcomes of women and minority ethnic solicitors in other areas of law. It may be that these environments are more conducive to women and minorities though more flexible working practices and operate with fewer time- 
intensive demands often associated with servicing corporate clients (Tomlinson et al 2013). However, an alternative proposition might be that larger law firms functioning similar to large corporate environments are more likely to have dedicated HR functions with developed and formalized diversity and inclusion policies designed to support women and minorities (Dobbin et al 2011) though, of course, not all will be effective (Pearce et al 2015).

In this paper we extend analysis of the career privileges and penalties enjoyed or endured by different gender and ethnic groups from the elite corporate sector to the entire solicitors' profession. Rather than measuring pay, we focus on progression to partnership in law firms - the ultimate indicator of success within the profession which is also a strong marker for current and future earning potential. In doing so, we also address an important but understudied aspect of inequality within organisations (Castilla 2008; Friedman and Laurison 2017; Kim and Zhao 2014).

\section{Data}

We obtained our data from the SRA, the regulatory body for solicitors in England in Wales. The data comprises individual records of practising solicitors in England and Wales which we were able to link to records of each regulated solicitors' firm. The SRA has a statutory duty to monitor diversity characteristics at both individual and firm level. Individual solicitors and solicitors' firms must re-register annually to be allowed to continue practicing law. Records are organised into three datasets. A major dataset records individual diversity characteristics including gender, ethnicity, religion, sexual orientation and disability alongside practice area, geographical location of a firm's headquarters and job title. This dataset was linked through each individual solicitor's unique identification number to a dataset of historic annual registration data containing records of previously held positions including information on headquarters' location and firm size (proxied by the number of fee 
earners). Finally, firm level data of 5,953 law firms in England and Wales spanning three years from 2014 until 2016, comprises aggregate workforce characteristics, including measures of practice area, geographical location and firm size, and diversity characteristics: the proportion of employees who are male; white; attended fee-paying school and are second generation in their family to attend university (the latter two being proxies for socioeconomic background). Firm identifiers in the individual dataset allowed linkage of the individual and firm level data, forming a single nested dataset where the population of individual solicitors are clustered on their respective law firms.

The main dataset is composed of 202,311 solicitors, which includes all lawyers in England and Wales except those who left the profession before 2006 (the SRA does not store older records in electronic format and did not make these records available for analysis). Those registered on the roll before 2006 constitute 61.5 per cent of the sample. The data are not prone to non-response and selection bias as having completed professional training, aspiring solicitors must must apply to the SRA to be entered on the roll. Then, they must apply annually for a certificate of practice which allows them to continue to practice as a solicitor. If a solicitor allows their practice certificate to lapse, they remain on the roll unless they apply to the SRA to be removed or are removed for professional misconduct. Solicitors who no longer practice formed 13.7 per cent of the sample.

Linking individual and firm-level data resulted in attrition, reducing the overall sample to 68,464 lawyers nested on their most recent employers. Data loss concerned mainly those who registered as a practising solicitor prior to 2006, reducing their share in the sample to 52.4 per cent, and those solicitors who no longer practice but remain on the roll (their share fell to 6.2 per cent). We ensured that data attrition was not systematically associated with key study variables (progression to partner level, gender and ethnicity) by comparing the respective frequencies between the original and nested solicitor-firm samples (no statistically significant difference was found). Furthermore 3.5 per cent of observations were 
lost due to missing values in relation to gender and ethnicity; data were missing completely at random but owing to a low proportion of missing values we did not use multiple imputation techniques. The dataset also contains information on disability, religion and sexual orientation. However, these variables were plagued by a high proportion of missing values. These issues aside, the data present an unrivalled opportunity to gain an insight into solicitors' career progression and the kinds of disadvantages experienced by women and minority ethnic groups within the profession.

\section{The social structure of the solicitors' profession}

In order to better understand the social structure of the profession, we first applied Latent Profile Analysis (LPA) to the firm-level data to cluster law firms into statistically independent subgroups (profiles). LPA is a type of finite mixture modelling premised on an iterative Expected Maximization algorithm (EM) that attempts to find maximum likelihood parameters of the statistical model assuming that it is derived from unobserved latent variables (Gibson 1959; Cloitre et al. 2013). LPA is a data driven approach pertinent to a research design in which a number of clusters is not assumed in advance. The analysis began with a baseline solution, assuming that the population is homogeneous. We then systematically increased the number of profiles by one until the model reached saturation, a condition where the number of estimated parameters is equal to the number of data points. The optimal number of profiles was identified using two comparative fit indices: integrated classification likelihood procedure (ICL) (Biernacki et al. 2000; McLachlan and Rathnayake 2014) and Bayesian Information Criterion (BIC) (Nylund et al. 2007). We have estimated Mahalanobis distance between the profiles as a proxy for statistical power that rendered further support for the optimal LPA solution (Jen-Yun Tein et al. 2013). 
To provide a comprehensive base for LPA we relied on three groups of variables collated at firm level: organisational diversity characteristics (the proportion of male and white solicitors in total workforce); socio-economic background of employees (the share of those who attended fee-paying school and the proportion of employees who are $2^{\text {nd }}$ generation university graduates); firm characteristics drawn from the geographical location of firm's headquarters, area of practice (distinguishing between corporate and private client work) and firm size derived by the number of fee earners. Firm characteristics were used as a proxy for prestige, allowing us to separate large firms with headquarters in central London operating in commercial areas of law from smaller, less prestigious regional based firms. Our measurements of the socio-economic background are not without limitations. Consistent with the literature on social mobility, other variables, notably parental occupation, would have been a better proxy for socio-economic background (Friedman, 2014). This type of information is not collected by the SRA. With that in mind, firm-level workforce data was essential for operationalising the measurements of socio-economic background, which are important indicators for attainment in a professional context and were not provided in individual level data.

Table 1 details measurement scales and descriptive statistics for each variable included in LPA.

Table 1 here

Table 2 outlines key characteristics of the firm profiles. We labelled the emerging profiles to reflect their key firm based characteristics: large corporate; regional mid-tier; city-boutique; regional niche; and high street. The lower portion of the table reports model fit coefficients, comparing the optimal solution with other plausible models. It also contains the predicted share of each profile in the overall population of law firms in England and Wales alongside the proportion of sole practitioner minority ethnic firms - those owned by minority ethnic 
solicitors which accounts for approximately 9 per cent of solicitors working in private practice (Law Society 2016: 15). These are important auxiliary variables in that these firms provide greater career prospects for minority ethnic groups. Achieving partnership status in such a firm may not be equivalent to doing so in a large corporate environment, in terms of seniority (number of fee earners overseen), prestige and remuneration, notably salary and profits share (Dixon and Seron 1995; Dinovitzier et al. 2009; Heinz et al. 2005).

Table 2 here

Figure 1 outlines how each established profile fares against the sample averages (mean score).

Figure 1 here

The large corporate profile is populated by firms employing on average up to 80 fee earners (twice as many as the average law firm) and operating in the commercial area of law. As expected, this profile has virtually no sole practices while the proportion of minority ethnic firms is negligible. The location of headquarters of these firms is slightly skewed towards central London (54 per cent chance) and the composition of the workforce is slightly skewed towards males. Large corporate firms employ more employees of minority ethnic background compared to the average firm, though not all will be employed as solicitors. The higher ethnic composition of corporate firms may be due to a high proportion of firms headquartered in London. The projected share of large corporate firms in the overall population of law firms is 18.2 per cent.

These firms have a higher share of privately educated employees compared with legal practices nationally. This chimes with other studies which note that the proportion of privately-educated partners working in London firms is nearly ten percentage points higher that the comparative figure for partners working in firms across England and Wales. The 
gap holds across the UK's largest law firms where the share of those who attended public school is up to 48 per cent whilst respective figure for the UK population is 7\% (Kirby, 2016).

Firms within regional mid-tier profile are located in major cities such as Manchester, Birmingham and Leeds. Operating in the commercial market, they are somewhat smaller in size (but still larger than the average law firm). This is the only profile in the sample where the share of female employees is higher than that of males. Compared to the average law firm, regional mid-tier firms employ more white workers, employees who attended state schools, and $2^{\text {nd }}$ generation university graduates. The regional mid-tier profile accounts for 14.1 per cent of law firms in England and Wales.

The City boutique profile is made up of firms predominantly located in central London which practice commercial law. They employ more males than females and have a higher share of minority ethnic employees than the average law firm. City boutique firms are considerably smaller than average, employing between 1 and 4 fee earners; around 43 per cent are sole practices. Firms in this profile account for 27.7 per cent of the population of minority ethnic firms and comprise 26 per cent of the solicitor firm population.

The two remaining profiles of law firms, regional niche and high-street, represent types of smaller firms with headquarters located mostly outside central London. The predicted shares of regional niche and high street firms were 20.1 per cent and 21.4 per cent respectively. While regional niche firms operate in the commercial market their high-street counterparts practice mostly private client work. Workforce characteristics of the profile of regional niche firms are around the sample average, with a slightly lower share of private educated employees. High-street firms employ a high proportion of first generation university graduates (65.7 per cent of the workforce or 34.5 per cent above the sample average) and a high share of white employees and those who attended state schools. The high street 
profile is made up largely by sole practices, accounting at the same time for 27.6 per cent minority ethnic law firms in England and Wales.

The LPA results show that the solicitors' profession is stratified into five types of law firm. From a socio-economic perspective, there is a hierarchy of firm types, at the top there is the large corporate cluster, followed by regional mid-tier and city boutique clusters which also practice in lucrative areas of commercial law in London or other major cities. Firm size is a key indicator of economic stratification here, with the typical leverage ratios of fee-earning lawyers to partners in larger firms suggesting large economic rewards from partnership in the larger firm types. For example, figures from The Lawyer Salary Survey 2016, show that, solicitors with one to three years post qualification experience earn, on average, around $£ 130,000$ in the 'magic circle' firms, $£ 90,000$ in the top $20-50$ UK law firms based in London, and $£ 50,000$ in top 100 UK law firms located in the regions.

At the same time, some firms within the city boutique cluster may benefit from higher value work in comparison to larger regional mid-tier by virtue of the type of commercial law they practice. Firms in the regional niche cluster practice commercial law but are typically smaller in size and not based in London or one of the major regional commercial centers. Firms in the high street cluster are also smaller, focusing on private client work (personal law).

\section{Intersectionality and career success in the solicitors' profession}

The next stage in the analysis is to understand how gender, ethnicity, and the intersection of gender and ethnicity are associated with different patterns of career success across the different firm profiles. To this effect, we generated a measure of progression to partner level: a dichotomous variable identifying whether solicitors have or have not yet reached partnership. This was our dependent variable. Independent variables were constructed on 
the basis of the intersection between gender and ethnicity categories. Given the ethnic composition of the profession we focused on the following categories: white males (an omitted variable in the regression analysis) and females, Asian males and females and black males and females. Asian and black minority ethnic groups are the two largest minority ethnic groups in England and Wales and within the legal profession (ONS 2012; Aulakh et al 2017). Remaining minority ethnic groups involving lawyers of Chinese descent and those of a mixed background were grouped as 'others' because absolute numbers were too small to permit meaningful regression analysis.

We used multilevel regression modelling to estimate whether the effect of the intersection of gender and ethnicity on career progression in the legal profession is additive, multiplicative or ameliorative. Our preference for multilevel modelling rests on its capacity to deal with nested data wherein individual respondents are clustered into higher level social structures such as regions, workplaces, households and so forth (Goldstein et al. 2002; Ogbonnaya and Valizade 2016).

Owing to the probability distribution of the dependent variable, random intercept logistic regression was performed to scrutinize the relationship between the intersection of gender and ethnicity and probability of progressing to partner. Thereafter, regression estimates were disaggregated into the established profiles of law firms to estimate whether and to what extent the type of law firm makes a difference to career progression in the legal profession.

To test whether relationships between intersections of female gender and minority ethnicity were associated with additive, ameliorative or multiplicative career penalties, first we derived average regression estimates for gender (females were compared to males) and minority ethnic groups using solicitors of a white ethnic background as a reference category. Regression models included the following control variables: registration date as a solicitor (to rule out 'recency bias' given those with a longer tenure in the profession have higher 
chances of reaching partnership); firm turnover; area of practice and headquarters' location to account for the effect of firm characteristics on career progression. Given that firm-level data is implicit in the established latent profiles of law firms, firm specific controls were used only in the baseline regression analysis prior to disaggregating the model into the firm profiles.

Table 3 reports descriptive statistics for the study variables.

Table 3 here

Baseline regression results across all law firm types are reported first. Table 4 details two regression models, reporting both raw regression coefficients (logarithm of odds) and odds ratios. Odds are calculated as the ratio between the probability of progressing to partner level and the probability of not reaching partnership. Consequently, odds ratios below one indicates a lower probability of progressing to partner level compared with the reference category. Model one uncovers basic penalties relating to gender and ethnicity separately, providing baseline estimates of average gender and ethnic penalties using males as a reference group. Odds equal to 0.24 indicate that females have significantly lower chances for progression to partner level than males. More specifically, female solicitors are on average four times less likely to progress to partnership than their male counterparts. A similar effect holds for minority ethnic groups who are less likely to reach partnership than white solicitors although the size of the effect was smaller than the one of gender (minority ethnic groups are two times less likely to progress to partner level than their white peers). Thus the gender penalty is more severe than the ethnic penalty, as other recent studies have found in the US (Mandel and Semyonov 2016; Greenman and Xie 2008). The first two bars in Figure 2 report odds ratios derived by model one, visualising the magnitude of the statistical relationships in question. 
Model two in Table 4 explicates the intersection of gender and ethnicity, using white males as a reference category. The lower portion of Figure 2 reports odds ratios corresponding to model two, preceded by the projected intersectional effect. The intersectional effect was calculated as a product of odds ratios for gender and ethnicity derived by model one. Coefficients reported in the table show whether the effect of the intersection of gender and ethnicity on progression to partner level is statistically significant while Figure 2 exemplifies the size of such effects. The intersectional effect appears to be additive among female minorities who suffer a double penalty (gender and ethnicity) compared with white males, and this is most clearly the case for Asian females. The effect for black females, who perform better than Asian females, is slightly ameliorative. This is in contrast to black males who have lower chances of progressing to partner level than male solicitors of Asian descent.

Figure 2 here

Next, we disaggregated model two into five regression models, one for each law firm profile. This allowed us to estimate whether the effect of the intersection between gender and ethnicity varies across the types of law firms. Table 5 reports regression coefficients while Figure 3 reports odds ratios using the predicted intersectional effect as a point of comparison (the first bar in each firm profile signifies the predicted intersectional effect, the same as in Figure 2). The intersection of gender and ethnicity was statistically significant among all firm profiles. The effect was clearly additive among large corporate firms and slightly stronger than additive for female solicitors of Asian descent among regional mid-tier firms. The intersection of gender and ethnicity was associated with lower chances of achieving partnership among other firm profiles too, but the size of the effect was weaker than additive. Notably, female lawyers of black ethnic origin outperformed or fared equal to Asian females across the board, except in high-street firms. The pattern is reversed for Black and Asian men across all firm profiles; Asian men are more likely to achieve partnership than Black men. Overall, disadvantaged groups are more likely to attain partnership in high street and 
city boutique firms compared with those clustered in other profiles. Women and minority ethnic groups are least likely to attain partnership in large corporate and regional mid-tier profiles where the most lucrative commercial work is concentrated.

Table 5 here

Figure 3 here

\section{Robustness checks}

While our data are representative of the legal profession in England and Wales a few concerns relating to data attrition and information loss for lawyers who quit the profession prior to 2006 have been addressed. To ensure that data attrition caused by the linkage of the solicitor and firm datasets has not biased the results of this study we performed an intersectional regression model without firm level data. This simpler single-level logistic regression based on the original sample returned regression coefficients, significance levels and estimates of an additive/ameliorative effect of the intersection of gender and ethnicity broadly similar to those reported in the present study.

Furthermore, we have split a linked solicitor-firm sample into three subsamples: lawyers registered on the roll before 2006 (a subsample prone to missing data); those registered as solicitors between 2006 and 2010 (lawyers in this subsample had from 6 to 10 years to progress to partner level); solicitors registered with the SRA after 2010 (a more recent cohort of lawyers). Once again, regression estimates were in line with the results reported above. Lastly, we have performed random selection intro three to five groups based on the registration date (the number of groups was dictated by the necessity to have enough observations in each group for a meaningful regression analysis). There was no significant deviation in regression estimates compared to the previous robustness checks and the main regression model, suggesting overall robustness of our analysis. 


\section{Discussion and conclusions}

Our dataset provides unique, detailed insight and robust empirical analysis of gender and ethnicity in the solicitors' profession, on a scale not previously possible. Returning to our primary research question: are the combined effects of gender and ethnicity on labour market outcomes are additive, multiplicative or ameliorative? Overall our research provides support for the additive assumption. Minority ethnic women face both a gender and ethnic penalty, but this penalty is not greater than the sum of separate ethnic and gender penalties. Results differ by ethnic group, showing for example that the penalty for black women is less pronounced than for Asian females, though the reverse is true among Black and Asian men. This kind of detail is not visible if the analysis is focused on gender and ethnic penalties separately, or when minority ethnic groups are not disaggregated. Our research shows that it is critical to distinguish minority ethnic groups to understand dynamic patterns of privilege and penalty in the UK labour market. This powerful large scale dataset has granted us the ability to look at ethnicity in more detail to provide a fine grained analysis.

LPA has provided a unique empirical classification of the solicitors' profession and the diversity of law firms in England and Wales. This analysis demonstrates that in addition to the well-known divide between commercial and private law (Heinz et al. 2005; Dinovitzer and Hagan 2014), there are five major firm profiles, with one of these, the large corporate firm, at the apex of the profession in terms of social and economic prestige. The city boutique and regional mid-tier firm profiles are also economically advantaged and display varying degrees of social privilege in their workforces. The two London centered profiles (city boutique and large corporate) have more ethnically diverse workforces, while regional midtier firms employ more women. Regional niche and high street clusters are smaller and based outside of major commercial centers, and are likely to be focused on private practice 
and/or lower value commercial work, with a workforce that is less advantaged in terms of socio-economic background, but are no more ethnically diverse.

When we examine more closely how women and minorities fare in the five different firm profiles, the results suggest that penalties are generally, but not consistently, additive by gender and minority ethnic group. For example, black women fare better than Asian women (in all but high street firms) and sometimes equal to white females (in city-boutique and regional mid-tier firms), suggesting that in some firm contexts, for women, black ethnicity has an ameliorative effect. Previous research on intersectionality rarely brings in variables and characteristics at the firm or occupational level and we believe this is a crucial next step in terms of extending debates on intersecting labour market inequalities.

While we cannot explain variations in additive and ameliorative effects with our data, drawing on other research we can provide tentative theoretical insights into why this might be the case. Variation in gender role expectations and degree of domestic specialisation across ethnic groups is one explanation (Mandel and Semyonov 2016; Greenman and Xie 2008). Research indicates middle class Asian women and men see professions as a route to upward social mobility (Archer 2011; Tomlinson et al 2013) and certainly SRA data shows a large increase in entry to the legal profession among both Asian men and women (Aulakh 2017). However, in the UK, Black women have greater labour market attachment than Asian women, notably those of Pakistani and Bangladeshi origin (ONS 2018), and this, in addition to differences in family formation, can explain why Black women experience slightly better labour market outcomes and promotion probabilities.

In terms of the reverse being true for men, Mandel and Semyonov (2016) also argue Black men often experience the greatest ethnic penalties in the labour market due to a range of factors including employer based preferences, stereotypes and racial discrimination, largely in line with UK based research on ethnic penalties (Berthoud 2000). Middle class Asian 
males are making inroads in greater numbers into the professions may be perceived as a better 'fit' with employer ideas of a professional worker than black men are. Research is limited in terms of how different minority ethnic groups experience access to the professions. This is certainly area of research requiring greater attention in the UK context (Archer 2011).

Furthermore, this article shows that while women and minority ethnic professionals have made progress accessing legal careers in recent decades, the probability of achieving partnership, notably among large corporate and regional mid-tier firms, remains markedly lower for them compared to white men. While this will not come as a surprise to many researching diversity in the professions, the strength of this finding lies in the ability to measure with precision the extent of white male privilege and locations where this advantage is most concentrated. Our results lend some support to the tournament thesis, notably in corporate firms - despite increasing diversity at entry level, the up-or-out system results in a white, male socio-economic elite maintaining their privilege in the most lucrative segments of law and in the most senior positions in large corporate law firms (Wilkins and Gulati 1996: Gorman and Kmec 2009). Our findings support Friedman and Laurison's (2017) argument that central London may not be the 'engine room' for social mobility within elite professional service firms, but rather remains a stronghold of existing inequalities, occupations operating socially and culturally based closure regimes that privilege white men of middle and upper class background. However, the tournament thesis is more relevant to those who enter and compete for commercial practice areas and promotion to partnership. As the qualitative research shows (Tomlinson et al 2013; Sommerlad et al 2013), not all solicitors aspire to work in these environments. Instead, either through genuine or adapted preferences, some solicitors seek work in private practice areas and smaller firms. Indeed, owning their own firm, having greater control and autonomy over working time and practices and/or operating in a local community may be more attractive than competing in a larger commercial environment. 
Our results suggest a need for further qualitative research to illuminate privileges and penalties in elite professions, both in terms of progression within and entry to the profession (Ashley and Empson 2017, Britton et al 2016) and in particular how different ethnic groups, intersected by gender, experience mobility within the profession. Quantitative research that can map career trajectories to partnership over time incorporating transitions between firms would also further advance our understanding of the different career paths and mobility experienced by solicitors of different ethnicities and genders within the profession.

\section{Notes/Acknowledgements}

The research that this manuscript is based on, and access to the data set used, was commissioned and authorised by the Solicitors Regulation Authority for England and Wales. We would like to thank the SRA for the opportunity to analyse this unique dataset, and their comments on an earlier draft.

\section{Bibliography}

Acker, J. 2006 'Inequality Regimes: Gender, Class, and Race in Organizations', Gender and Society 20(4): 441-464.

Anthias, F. and Yuval-Davis, N. 1993 Racialized Boundaries: Race, Nation, Gender, Colour and Class and the Anti-Racist Struggle. London: Routledge.

Archer, L (2011) 'Constructing Minority Ethnic Middle-class Identity: An Exploratory Study with Parents, Pupils and Young Professionals' Sociology, 45(1): 134-151.

Ashley, L. and Empson, L. 2017 'Understanding Social Exclusion in Elite Professional Service Firms: Field Level Dynamics and the 'Professional Project', Work, Employment and Society 31(2): 211-229.

Ashley, L. and Empson, L. 2013 'Differentiation and discrimination: Understanding social class and social exclusion in leading law firms', Human Relations 66(20): 219-244.

Aulakh, S. Charlwood, A., Muzio, D. Tomlinson, J and Valizade, D. 2017 Mapping advantages and disadvantages: Diversity in the legal profession in England and Wales. SRA: Birmingham. 
Berthoud, R. 2000 'Ethnic employment penalties in Britain', Journal of Ethnic and Migration Studies 26(3): 389-416.

Bidwell, M., Briscoe, F., Fernandez-Mateo, I., and Sterling, A. 2013 The Employment Relationship and Inequality: How and Why Changes in Employment Practices are Reshaping Rewards in Organizations', |The Academy of Management Annals 7(1): \$1-121.

Biernacki, C., Celeux, G., Govaert, G. 2000 'Assessing a mixture model for clustering with the integrated completed likelihood', IEEE Trans. Pattern Analysis and Machine Intelligence, 22(7): 719-725.

Bolton, S. and Muzio, D. 2007 'Can't Live with Em; Can't Live Without Em: Gendered Segmentation in the Legal Profession', Sociology 41(1): 47-64.

Briscoe, F. and Kellogg, K. 2011 'The Initial Assignment Effect: Local Employer Practices and Positive Career Outcomes for Work-Family Program Users', American Sociological Review 76(2): 291-319.

Britton J., Dearden L., Shephard, N. and Vignoles A 2016 How English domiciled graduate earnings vary with gender, institution attended, subject and socio-economic background, London: Institute for Fiscal Studies.

Browne, I., and Misra, J. 2003 'The intersection of gender and race in the labour market', Annual Review of Sociology 29(1): 487-513.

Castilla, E.J. 2008 'Gender, Race, and Meritocracy in Organizational Careers', American Journal of Sociology, 113(6): 1479-1526.

Cloitre, M., Garvert, D., Weiss, B., Carlson, E. and Bryant, R. 2014 'Distinguishing PTSD, Complex PTSD, and Borderline Personality Disorder: A latent class analysis', European Journal of Psychotraumatology 5(1): 250-297.

Crenshaw, K. 1989 'Demarginalizing the Intersection of Race and Sex: A Black Feminist Critique of Antidiscrimination Doctrine, Feminist Theory and Antiracist Politics', University of Chicago Legal Forum 1(8): 139-167.

Crenshaw, K. 1993 'Mapping the margins: intersectionality, identity politics and violence against women of color', Stanford Law Review 43: 1241-1299.

Dinovitzer, R. and Hagan, J. 2014 'Hierarchical structure and gender dissimilarity in American legal labor markets', Social Forces 92(3): 929-955.

Dinovitzer, R., Reichman, N. and Sterling, R. 2009 'The Differential Valuation of Women's Work: A New Look at the Gender Gap in Lawyers' Incomes', Social Forces 88(2): 819-864.

Dixon, J. and Seron. C. 1995 'Stratification in the Legal Profession: Sex, Sector, and Salary', Law \& Society Review 29(3): 381-412.

Dobbin, F., Kim, S. and Calev A. 2011 'You Can't Always Get What You Need: Organizational Determinants of Diversity Programs', American Sociological Review 76(3): 386-411. 
Friedman, S. 2014 'The price of the ticket: Rethinking the experience of social mobility', Sociology 48(2): 352-368.

Friedman, S. and Laurison, D. 2017 'Mind the gap: financial London and the regional class pay gap', British Journal of Sociology 68(3): 474-511.

Galanter, M. and Palay, T. 1991 'Tournament of Lawyers: The Transformation of the Big Law Firm: Transformation of a Big Law Firm', Chicago: University of Chicago Press.

Goldstein, H., Browne, W., and Rasbash, J. 2002 'Partitioning variation in multilevel models', Understanding Statistics: Statistical Issues in Psychology, Education and the Social Sciences 1(4): 223-231.

Gorman, E. and Kmec, J. 2009 'Hierarchical rank and women's organizational mobility: Glass ceilings in corporate law firms', American Journal of Sociology 114(5): 1428-1474.

Gorman, E. 2006 'Work Uncertainty and the Promotion of Professional Women: The Case of Law Firm Partnership', Social Forces 85(2): 865-90.

Greenman, E. and Xie, Y. 2008 'Double Jeopardy: The interaction of gender and race on earnings in the US', Social Forces 86(3): 1217-1244.

Hanlon, G. 2004 'Institutional Forms and Organizational Structures: Homology, Trust and Reputational Capital in Professional Service Firms', Organization 11(2): 186-210.

Heinz, J. and Lauman, E.O. 1982 Chicago Lawyers: The Social Structure of the Bar. Chicago: The University of Chicago Press.

Heinz, J.P., Nelson, R.L., Sandefur, R.L. and Laumann, E.O. 2005 Urban Lawyers: The New Social Structure of the Bar. Chicago: The University of Chicago Press.

Hill Collins, P. 1993 Towards a new vision: race, class and gender as categories of analysis and connection, 'Race, Sex and Class, 1(1): 25-45.

Hooks, B. 1984 Feminist Theory: From Margin to Center. Cambridge MA: South End Press.

Kay F. and Hagan, J. 1998 'Raising the bar: The gender stratification of law-firm capital', American Sociological Review 63(5): 728-743.

Kay, F., and Gorman, E. 2008 'Women in the Legal Profession', Annual Review of Law and Social Science 4, 299-332.

Kay, F. and Gorman, E. 2016 'Which kinds of law firms have the most minority lawyers?' in Headworth S., Nelson, R.L., Dinovitzer, D. and Wilkins, D.B. (eds.) Race, Gender, and Class in Legal and Professional Careers. Cambridge University Press.

Kay. F., and Hagan, J. 1995 'The Persistent Glass Ceiling: Gendered Inequalities in the Earnings of Lawyers', British Journal of Sociology 46(2): 279-310.

Kim, C. and Zhao, Y. 2014 'Are Asian American Women Advantaged? Labor Market Performance of College Educated Female Workers', Social Forces, 93(2): 623-652.

Ladinsky, J. 1963 'Careers of Lawyers, Law Practice, and Legal Institutions', American Sociological Review 28(1): 47-54. 
Laurison, D. and Friedman, S. 2016 'The Class Pay Gap in Higher Professional and Managerial Occupations', American Sociological Review 81(4): 668-95.

Law Society 2012 The Legal Services Industry Part 2 -Main Sectors. London: Law Society.

Law Society 2016 Diversity Profile of the Solicitors' Profession http://www.lawsociety.org.uk/support-services/research-trends/promoting-diversity-in-thelegal-profession/

Lazarsfeld, P. and Henry, N. 1968 Latent structure analysis. Boston, MA: Houghton Mifflin.

Malhotra, N., Morris, T. and Smets, M. 2010 'New career models in UK professional service firms: from up-or-out to up-and-going-nowhere?', The International Journal of Human Resource Management, 21(9): 1396-1413.

Mandel, H. and Semyonov, M. 2016 'Going Back in Time? Gender Differences in Trends and Sources of the Racial Pay Gap, 1970 to 2010', American Sociological Review 81(5): 1039-1068.

McCall, L. 2005 'The complexity of intersectionality', Signs: Journal of Women in Culture and Society 30(3): 1771-1800.

McLachlan, G. and Rathnayake, S. 2014 'On the number of components in a Gaussian mixture model', Wiley Interdisciplinary Reviews: Data Mining and Knowledge Discovery, 4(5): 341-355

Nylund, K., Asparouhov, T., and Muthen, B. 2007 'Deciding on the number of classes in latent class analysis and growth mixture modeling: A Monte Carlo simulation study', Structural Equation Modeling 14(4): 535-569.

Ogbonnaya, C. and Valizade, D. 2016 'High performance work practices, employee outcomes, and organizational performance: a 2-1-2 multilevel mediation analysis', International Journal of Human Resource Management. 26(3): 351-368.

ONS. 2012 Ethnicity and National Identity in England and Wales: 2011. [online] Available atthttps://www.ons.gov.uk/peoplepopulationandcommunity/culturalidentity/ethnicity/articles/ ethnicityandnationalidentityinenglandandwales/2012-12-11\#more-census-analysis. [Accessed 05/02/2018]

ONS. 2018 UK labour market: January 2018. Estimates of employment, economic inactivity and other employment-related statistics for the UK. [online] Available at: https://www.ons.gov.uk/employmentandlabourmarket/peopleinwork/employmentandemplo yeetypes/bulletins/uklabourmarket/january2018. [Accessed 10/02/2018]

Parkin, F. 1979 Marxism and Class Theory. London: Tavistock.

Pearce, R., Wald, E., and Ballakrishnen S. 2015 'Difference blindness vs. bias awareness: why law firms with the best intentions have failed to create diverse partnerships', Fordham Law Review 83(5): 2407-2457. 
Sommerlad H. and Sanderson P. 1998 Gender, Choice and Commitment: Women Solicitors in England and Wales and the Struggle for Equal Status. London: Ashgate.

Sommerlad, H. Webley, L; Muzio, D; Tomlinson, J and Duff, L 2013 Diversity in the legal profession in England and Wales: a qualitative study of barriers and individual choices. London: University of Westminster Law Press

Tein, J.Y., Coxe, S. and Cham, H. 2013 'Statistical power to detect the correct number of classes in latent profile analysis', Structural Equation Modelling: a Multidisciplinary Journal 20(4): 640-657.

Tomlinson, J., Muzio, D., Sommerlad, H., Webley, L. and Duff, L. 2013 'Structure, agency and the career strategies of white women and BME individuals in the legal profession', Human Relations. 66(2): 245-269

Walby, S. Armstrong, J. and Strid, S. 2012 'Intersectionality: Multiple Inequalities in Social Theory', Sociology 46(2): 224-240.

Wald, E. 2008 'The Rise and Fall of the WASP and Jewish Law Firms', Stanford Law Review. 60(6): 1803-1866.

Webley, L., Tomlinson, J., Muzio, D. Sommerlad, H and Duff, L. 2016 'Access to a legal career in England and Wales: Race Class and Educational Background', in Hayworth, S., Nelson, R, Wilkins, D and Dinovitzer, R. (eds.) Diversity in Practice. Cambridge: Cambridge University Press.

Wilkins, D. and Gulati, G. 1996 'Why are there so few black lawyers in corporate law firms? An institutional analysis', California Law Review 84(3): 496-625.

Witz, A. 1990 'Patriarchy and professions: The gendered politics of occupational closure', Sociology 24(4): 675-690.

Woodhams, C., Lupton, B., and Cowling, M. 2015 'The snowballing penalty effect: Multiple disadvantage and pay', British Journal of Management 26(1): 63-77

Yuval-Davis, A. 2007 'Intersectionality, citizenship and contemporary politics of belonging' Critical Review of International Social and Political Philosophy 10(4): 561-574 


\begin{tabular}{|c|c|c|}
\hline & Measurement scale & $\begin{array}{c}\text { Descriptive statistics } \\
\text { Mean } \\
\text { (st deviation) }\end{array}$ \\
\hline & \multicolumn{2}{|c|}{ Workforce diversity characteristics } \\
\hline Gender & $\%$ of males & $\begin{array}{c}54.4 \\
(0.32)\end{array}$ \\
\hline Ethnicity & $\%$ of white employees & $\begin{array}{c}60.5 \\
(0.38)\end{array}$ \\
\hline & \multicolumn{2}{|c|}{ Socio-economic background } \\
\hline $\begin{array}{l}\text { Private } \\
\text { schooling } \\
\text { Higher } \\
\text { education }\end{array}$ & $\begin{array}{l}\% \text { attended fee paying } \\
\text { schools } \\
\% \text { of } 2 \text { nd and further } \\
\text { generations of } \\
\text { university graduates }\end{array}$ & $\begin{array}{c}45.6 \\
(0.36) \\
68.0 \\
(0.33)\end{array}$ \\
\hline & \multicolumn{2}{|c|}{ Firm characteristics } \\
\hline Fee earners & $\begin{array}{c}0-0 \\
1-1 \\
2-2 \text { to } 4 \\
3-5 \text { to } 10 \\
4-11 \text { to } 25 \\
5-26 \text { to } 80 \\
6-\text { over } 81\end{array}$ & $\begin{array}{c}2.47 \\
(1.24)\end{array}$ \\
\hline Area of practice & $\begin{array}{c}1 \text { - private client work } \\
2- \\
\text { commercial/corporate }\end{array}$ & $\begin{array}{l}1.88 \\
(0.33)\end{array}$ \\
\hline $\begin{array}{l}\text { Headquarters' } \\
\text { location }\end{array}$ & $\begin{array}{l}1 \text { - outside of central } \\
\text { London } \\
2 \text { - central London }\end{array}$ & $\begin{array}{c}1.33 \\
(0.47)\end{array}$ \\
\hline
\end{tabular}


Table 2: Latent profiles of law firms

\begin{tabular}{|c|c|c|c|c|c|}
\hline & $\begin{array}{l}\text { Large } \\
\text { corporate }\end{array}$ & $\begin{array}{c}\text { City- } \\
\text { boutique }\end{array}$ & $\begin{array}{l}\text { High- } \\
\text { street }\end{array}$ & $\begin{array}{l}\text { Regional- } \\
\text { niche }\end{array}$ & Regional mid-tier \\
\hline Gender (male, \%) & 55 & 57.7 & 53.9 & 50.3 & 46.1 \\
\hline Ethnicity (white, \%) & 57.6 & 54.9 & 64.7 & 62.4 & 65.6 \\
\hline Private schooling (\%) & 50.2 & 57.4 & 39.8 & 38.6 & 36.8 \\
\hline $\begin{array}{l}2^{\text {nd }} \text { generation and beyond } \\
\text { university graduates }(\%)\end{array}$ & 79.9 & 83.5 & 34.3 & 67.8 & 75 \\
\hline Fee earners (average) & 4.49 & 1.91 & 1.51 & 2.00 & 3.00 \\
\hline Area of practice (average) & 2.00 & 2.00 & 1.43 & 2.00 & 2.00 \\
\hline \multirow[t]{2}{*}{$\begin{array}{l}\text { Headquarters location } \\
\text { (average) }\end{array}$} & 1.54 & 1.66 & 1.29 & 1.00 & 1.00 \\
\hline & \multicolumn{5}{|c|}{ Sole practitioners and minority ethnic firms } \\
\hline $\begin{array}{l}\text { Minority ethnic firms (100 } \\
\text { per cent minority ethnic } \\
\text { staff; \% share across the } \\
\text { profiles) }\end{array}$ & $1.5^{*}$ & 27.7 & 27.6 & 21.4 & 6.1 \\
\hline \multirow[t]{5}{*}{$\begin{array}{l}\text { Sole practices (\% share } \\
\text { within the profile) }\end{array}$} & 0 & 43.5 & 60.1 & 0 & 0 \\
\hline & \multicolumn{5}{|c|}{$\begin{array}{c}\begin{array}{c}\text { Profile share in the population of law firms (derived by posterior } \\
\text { probabilities) }\end{array} \\
\end{array}$} \\
\hline & $18.2 \%$ & $26.2 \%$ & $21.4 \%$ & $20.1 \%$ & $14.1 \%$ \\
\hline & \multicolumn{5}{|c|}{ Model fit } \\
\hline & \multicolumn{2}{|c|}{ Model with four profiles } & \multicolumn{2}{|c|}{$\begin{array}{c}\text { Model with five } \\
\text { profiles }\end{array}$} & Model with six profiles \\
\hline ICL & \multicolumn{2}{|c|}{-76708.87} & -57157.04 & & -81102.78 \\
\hline BIC & \multicolumn{2}{|c|}{-75942.82} & -57085.7 & & -80401.35 \\
\hline
\end{tabular}


Table 3: Descriptive statistics

\begin{tabular}{|c|c|c|}
\hline & Measurement scale & Per cent \\
\hline & \multicolumn{2}{|c|}{ Main study variables } \\
\hline \multirow[t]{2}{*}{$\begin{array}{l}\text { Progression to partner } \\
\text { level (share of } \\
\text { partners) }\end{array}$} & Categorical dichotomous & $18.1 \%$ \\
\hline & \multicolumn{2}{|c|}{ Intersection of gender and ethnicity } \\
\hline White males & \multirow{8}{*}{ Categorical nominal } & $43.7 \%$ \\
\hline White females & & $41.9 \%$ \\
\hline Asian males & & $4.0 \%$ \\
\hline Asian females & & $4.6 \%$ \\
\hline Black males & & $0.7 \%$ \\
\hline Black females & & $1.1 \%$ \\
\hline Males (other) & & $1.5 \%$ \\
\hline \multirow{3}{*}{ Females (other) } & & $2.4 \%$ \\
\hline & \multicolumn{2}{|c|}{ Control variables } \\
\hline & \multicolumn{2}{|c|}{ Registration date } \\
\hline$<2000$ & \multirow{5}{*}{ Categorical ordinal } & $36.0 \%$ \\
\hline 2001-2005 & & $16.4 \%$ \\
\hline 2006-2010 & & $22.1 \%$ \\
\hline 2011-2016 & & $25.5 \%$ \\
\hline & & \\
\hline Below 35 & \multirow{4}{*}{ Categorical ordinal } & $29.8 \%$ \\
\hline $35-49$ & & $42.7 \%$ \\
\hline Above 50 & & $27.5 \%$ \\
\hline \multicolumn{2}{|c|}{ Exit } & \\
\hline $\begin{array}{l}\text { Exit from the } \\
\text { profession (proportion } \\
\text { of those who no longer } \\
\text { practice) }\end{array}$ & Categorical dichotomous & $6.2 \%$ \\
\hline & size: 68464 observations & \\
\hline
\end{tabular}


Table 4: Multilevel regression analysis (complete sample)

$\operatorname{Pr}($ Partner)

$\log ($ Odds)/Odds ratio

(standard error)

Model one

Gender $\quad-1.434 * * * / 0.24$

(0.018)

Ethnicity $-0.672 * * * / 0.51$

(0.028)

Model two

White females $-1.491 * * * / 0.22$

(0.020)

Asian females

$-1.908 * * * / 0.15$

(0.049)

Other females

$-2.044 * * * / 0.10$

(0.072)

Black females

$-1.761 * * * / 0.17$

(0.094)

Asian males

$-0.835^{* * * / 0.43}$

(0.046)

Other males

$-0.879 * * * / 0.38$

(0.071)

Black males

$-1.158 * * * / 0.31$

(0.105)

Sample size: 68464 observations nested on 5953 law firms

Significance codes: ' $* * *^{\prime} p<0.0011^{\prime * * \prime} p<0.01 ; p<{ }^{\prime * \prime} 0.05$

$\mathrm{ICC}_{1}(\mathrm{Pr})=14.6 \%$ 
Table 5: Multilevel regression analysis by profiles of law firms

\begin{tabular}{|c|c|c|c|c|c|}
\hline & $\begin{array}{c}\text { Large } \\
\text { corporate }\end{array}$ & $\begin{array}{l}\text { Regional mid- } \\
\text { tier }\end{array}$ & City-boutique & $\begin{array}{l}\text { Regional- } \\
\text { niche }\end{array}$ & High street \\
\hline & $\begin{array}{c}\text { Log } \\
\text { (odds)/odds } \\
\text { (std error) }\end{array}$ & $\begin{array}{c}\text { Log } \\
\text { (odds)/odds } \\
\text { (std error) }\end{array}$ & $\begin{array}{c}\text { Log } \\
\text { (odds)/odds } \\
\text { (std error) } \\
\end{array}$ & $\begin{array}{c}\text { Log } \\
\text { (odds)/odds } \\
\text { (std error) }\end{array}$ & $\begin{array}{c}\text { Log } \\
\text { (odds)/odds } \\
\text { (std error) }\end{array}$ \\
\hline \multirow{16}{*}{$\begin{array}{l}\text { White } \\
\text { females } \\
\text { Asian } \\
\text { females } \\
\text { Black } \\
\text { females } \\
\text { Asian } \\
\text { males } \\
\text { Black } \\
\text { males } \\
\text { Other } \\
\text { males } \\
\text { Other } \\
\text { females }\end{array}$} & $-1.507^{* * *} / 0.22$ & $-1.640^{* * *} / 0.19$ & $-1.353^{* * *} / 0.26$ & $-1.309^{* \star *} / 0.27$ & $-0.689^{* * *} / 0.50$ \\
\hline & $\begin{array}{c}(0.022) \\
-2072^{* * *} / 0.13\end{array}$ & $\begin{array}{c}(0.0 / 3) \\
-2269^{* * *} / 0.10\end{array}$ & $\begin{array}{c}(0.0 / 1) \\
-1617^{* * *} / 020\end{array}$ & $\begin{array}{c}(0.107) \\
-1720^{* * *} / 0.18\end{array}$ & $\begin{array}{r}0.11 \\
-1020^{* *}\end{array}$ \\
\hline & $(0.066)$ & $(0.154)$ & $(0.122)$ & $(0.181)$ & $(0.181)$ \\
\hline & $\begin{array}{c}-2.083^{* * *} / 0.12 \\
(0.141)\end{array}$ & $\begin{array}{c}-1.788^{* * *} / 0.17 \\
(0.356)\end{array}$ & $\begin{array}{c}-1.297^{\star * *} / 0.27 \\
(0.177)\end{array}$ & $\begin{array}{c}-1.714^{* * *} / 0.18 \\
(0.367)\end{array}$ & $-1.222^{* * *} / 0.29$ \\
\hline & $-0.921^{* * *} / 0.40$ & $-1.076^{* * *} / 0.34$ & $-0.641^{* * *} / 0.53$ & $-0.964^{* * *} / 0.38$ & $-0.623^{* * *} / 0.54$ \\
\hline & $(0.063)$ & $(0.132)$ & $(0.118)$ & $(0.152)$ & $(0.154)$ \\
\hline & $-1.246^{* * *} / 0.29$ & $-1.335^{* * *} / 0.26$ & $-0.998^{* * *} / 0.37$ & $-1.562^{* * *} / 0.21$ & $-0.746^{* *} / 0.47$ \\
\hline & $(0.161)$ & $(0.339)$ & $(0.195)$ & $(0.419)$ & (0.285) \\
\hline & $\begin{array}{c}-0.874^{\star * *} / 0.42 \\
(0.082)\end{array}$ & $\begin{array}{c}-0.954^{\star *} / 0.38 \\
(0.329)\end{array}$ & $\begin{array}{c}-0.689^{* * *} / 0.50 \\
(0.208)\end{array}$ & $\begin{array}{c}-1.539^{* * *} / 0.29 \\
(0.384)\end{array}$ & $\begin{array}{c}-0.598 / 0.55 \\
(0.330)\end{array}$ \\
\hline & $-2.144^{* * *} / 0.12$ & $-2.323^{* * *} / 0.10$ & $-1.799^{* * *} / 0.17$ & $-1.249^{* * *} / 0.21$ & $-1.225^{* * *} / 0.29$ \\
\hline & $(0.087)$ & (0 333) & (0 185) & & \\
\hline & Sample size: & Sample size: & Sample size: & Sample size: & Sample size: \\
\hline & 61949 & 5632 solicitors & 1608 solicitors & 3505 solicitors & 2319 solicitors \\
\hline & solicitors & nested on 866 & nested on 7048 & nested on 1236 & nested on \\
\hline & $\begin{array}{l}\text { nested on } \\
1112 \text { law firms }\end{array}$ & law firms & law firms & law firms & 1304 law firms \\
\hline & \multicolumn{5}{|c|}{ Significance codes: ‘***’ $p<0.001 ;{ }^{* * * \prime} p<0.01 ; p<$ ‘*’ 0.05} \\
\hline
\end{tabular}


